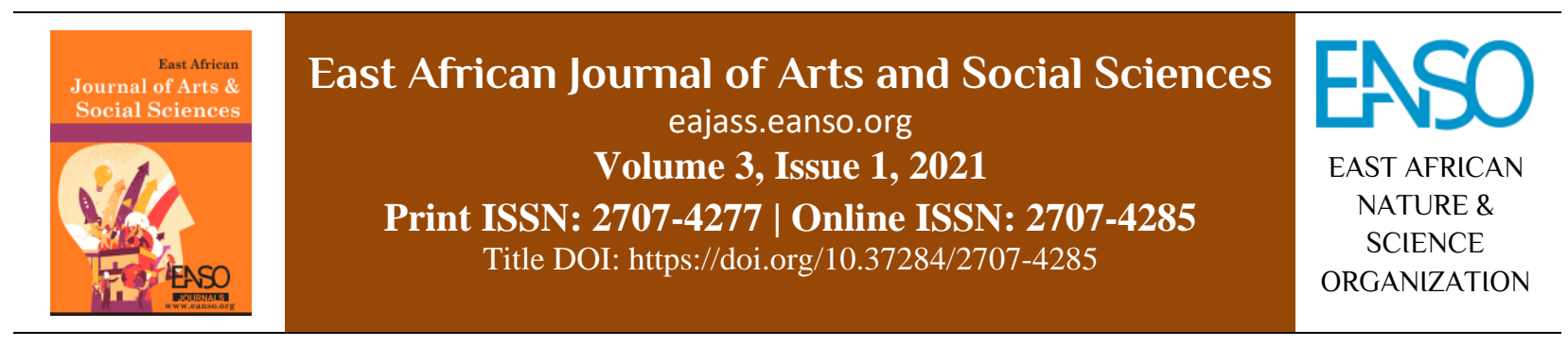

Original Article

\title{
Ethnic Federalism in Ethiopia: Reflecting on Diversity and Ethnic Identity.
}

\author{
Kshipra Vasudeo ${ }^{*}$
}

${ }^{1}$ School of International Studies, Jawaharlal Nehru University, New Delhi, India.

*Correspondence email: kshipra.vasu@gmail.com.

Article DOI: https://doi.org/10.37284/eajass.3.1.407

\section{Article history: ABSTRACT}

09 September 2021 Ethiopia formed an ethnic federal system in 1991, which recognized ethnic autonomy entirely while ensuring the country's unity. The new Constitution

Keywords: established a federal structure focused primarily on ethnic territorial units. The constitution ambitions to achieve ethnic freedom and equality by maintaining the

Ethiopia, state. Ethiopian politics has shifted to a federal liberal and plural system since the

Africa, military dictatorship ended, as ethnic groups sought to exist under a federal structure

Ethnic that could preserve the country's stability and diversity. The federal arrangement is

Federalism noteworthy because its Constitution allows for the inheritance of every ethnic

Identity political parties to unite along ethnic lines. It is a worthwhile case study because it is an exception to the general trend in Africa. This paper examines how ethnic Federalism is a vital part of the Ethiopian Constitution and gives ethnic autonomy and identity in Ethiopian politics. Theoretical understanding of Federalism and ethnic Federalism in Ethiopia.

\section{APA CITATION}

Vasudeo, K. (2021). "Ethnic Federalism in Ethiopia: Reflecting on Diversity and Ethnic Identity. East African Journal of Arts and Social Sciences, 3(1), 147-155. https://doi.org/10.37284/eajass.3.1.407

\section{CHICAGO CITATION}

Vasudeo, Kshipra. 2021. "Ethnic Federalism in Ethiopia: Reflecting on Diversity and Ethnic Identity". East African Journal of Arts and Social Sciences 3 (1), 147-155. https://doi.org/10.37284/eajass.3.1.407

\section{HARVARD CITATION}

Vasudeo, K. (2021) "Ethnic Federalism in Ethiopia: Reflecting on Diversity and Ethnic Identity", East African Journal of Arts and Social Sciences, 3(1), pp. 147-155. doi: 10.37284/eajass.3.1.407.

\section{IEEE CITATION}

K. Vasudeo, "Ethnic Federalism in Ethiopia: Reflecting on Diversity and Ethnic Identity", EAJASS, vol. 3, no. 1, pp. 147-155, Sep 2021. 


\section{MLA CITATION}

Vasudeo, Kshipra. "Ethnic Federalism in Ethiopia: Reflecting on Diversity and Ethnic Identity". East African Journal of Arts and Social Sciences, Vol. 3, no. 1, Sep 2021, pp. 147-155, doi:10.37284/eajass.3.1.407.

\section{INTRODUCTION}

The Post-Cold War world regime has changed, and it has affected both the northern and southern hemispheres. This was the time when geopolitics altered to a more considerable extent to redesign world politics. In this changing pattern, global politics has also influenced and transformed African politics. After the 1990s, when the Soviet Union disintegrated, it could no longer give political and economic support to its African friend Ethiopia. Furthermore, democratization and the free-market system have become a post-cold war world phenomenon (J. Erk, 2017). During this period, Ethiopian politics was drastically changed from military domination of rule to democratization and federalization with the entire ethnic group. After the 1990s, South Africa and Ethiopia's Federalism became the political tool for the balance of unity and diversity (Fiseha, 2012; Styler \& Metler, 2001).

Ethnic-based Federalism, influenced by a neoLeninist democratic paradigm known as revolutionary democracy, was one of the central values instituted by Ethiopia's post-1991 regime, which came to power after a successful armed struggle. The ruling Tigray People's Liberation Front (later the Ethiopian People's Liberation Front) devised this model. The ethnic prejudice of the EPRDF was to be the foundation of politics (Abbinnk, 2011).

After a long time (from 1974 to 1991), Ethiopians witnessed the Derg military regime. The Derg regime came to power after overthrowing Emperor Haile Selassie in 1975 . The initially named military rule, Derg, promised to provide political and economic modernization to Ethiopia, specifically to the marginalized rural areas and minorities underdeveloped under imperial power. But later on, the heavily promoted military and arbitrary rule became the authoritarian military rule in which various ethnic conflicts and tensions got increased. During the imperial power, mostly speaking Amharic and orthodox Christianity expands in the southern areas. During imperialism, ethnic tension was the surface of the below (J. Erk, 2017). But when the military rule of the Derg regime arose, ethnic tension remained with the uprising against the military power, and finally, the multi-ethnic group called EPRDF (The Ethiopian People's Revolutionary Democratic Front) overthrown the military rule of the Derg regime and established the Ethnic Federalism with respect of equal representation. The main purpose of achieving ethnic Federalism in Ethiopia was to maintain the diversity of Ethiopia as a political unit. Also, the reassertion of ethnic identity plays a significant role in establishing ethnic Federalism to gain equal representation in the political institutions of Ethiopian politics. Thus, this paper highlights: how ethnic Federalism reflected the diversity and ethnic identity of Ethiopia.

\section{An Overview of the Ethnic Diversity in Ethiopia}

Ethiopia is strategically situated in the north-eastern part of Africa, popularly known as the "horn of Africa." Ethiopia is also considered the oldest civilization and statehood in the world. It is the only country on the African continent that is never colonized. It has been known for its rich and incredible diversity due to its multi-ethnic and multi-linguistic traits. It has eighty different languages with approx. 200 dialects. Ethiopia has a vast ethnic diversity with 84 distinct ethnic groups. Twelve of these ethnic groups have a population of over half a million or more; out of the total population (around 53 million), the two major ethnic groups (the Oromo and the Amhara) constitute over 62 percent of the total population. The third-largest ethnic group is Tigray. It comprises only 6 percent of the total population, but it is the most politically dominated ethnic group since 1991. In 1994, four other ethnic groups, namely Somalia, Gurage, Sidama, and Welaita, had over one million population. These seven largest ethnic groups comprise 84.5 percent of the country's population. According to FDRE Central Statistical Authority (Addis Ababa, June 1999), from a religious point of view, Christianity is the largest religious group as 61.7 percent of the population are Christians, Muslims constitute 32.8 percent, traditional 4.6 percent, others 0.9 percent, 
not stated 0.1 percent. The Orthodox Christians constitute 50.6 percent, Protestants constitute 10.2 percent, and Catholics comprise 0.9 percent of the total population (Habtu, 2003). The "Traditional" category above refers to those Ethiopian people who follow indigenous culture and religion.

Table 1: Ethnic Group of Ethiopia

\begin{tabular}{lll}
\hline Rank & Ethnic Groups & Estimated Population Living in Ethiopia (till present) \\
\hline 1 & Oromo & $34,216,242$ \\
2 & Amhara & $26,855,771$ \\
3 & Somali & $6,186,774$ \\
4 & Tigrayan & $6,047,522$ \\
5 & Sidama & $3,978,633$ \\
6 & Gurage & $2,506,539$ \\
7 & Welayta & $2,257,874$ \\
8 & Afar & $1,720,759$ \\
9 & Hadiya & $1,710,812$ \\
10 & Gamo & $1,482,041$ \\
& Other Groups & $12,532,693$ \\
\hline Source: & World Atlas & $(2018)$, (online) URL: https://www.worldatlas.com/articles/ethnic-groups-of-
\end{tabular}
ethiopia.html.

These are the major ethnic groups in Ethiopia. Other groups and migrated people are also there, but their population is less than indigenous people. Hence, the Ethiopian Constitution addresses this diversity of equal representation and development. According to the Ethiopia report 2017,

The Federal Democratic Republic of Ethiopia's constitution Article 41(9) and Article 91(3) precisely how the government duties and responsibilities to protect, preserve and support the cultural heritage and arts. The Constitution highlights the importance of the diversity of cultural expressions in Ethiopia since 1994. Cognizant of the fact that all policies, measures, and international agreements ratified by Ethiopia are proven to agree with the constitutional pillars, the upper mentioned and other various articles pledged in favour of the cultural expressions have gotten ample opportunities and conducive platform both to be underpinned by policies and dignified (UNESCO, 2017).

The Ethiopian Constitution gives a proper representation to each section of the ethnic group with autonomy. Ethnic Federalism in Ethiopia reflects on diversity and ethnic identity. Further, this paper discusses the concept of Federalism, Ethnic Federalism, and how the ethnic federal system manages Ethiopian political diversity and ethnic identity.

\section{The Concept of Federalism, Ethnic Federalism and Identity in Ethiopian Politics}

Federalism is an idea of inclusivity popularized by the United States of America in the modern context. However, it has roots in the Urukwa nation, one of the main Native American tribes. It has roots in various ancient civilizations of the world.

In the modern-day, Switzerland is one of the examples of successful Ethnic Federalism. But Federalism has nothing to do with ethnicity but is related to regionalism. It has to do with when a larger country gives a limited amount of power to a Federal Government. Usually, that involves dealing with other Foreign Sovereigns nations and then devolves the rest of the power at local levels, which can be called Cantons, Districts, and States or, in Ethiopian terms, Kudlins.

Ethnic Federalism is the idea that is based on ethnicity. It could mean culture, language, religion, biology, or one's blood. In Ethiopia, the form of Ethnic Federalism was based on Linguistics and was imposed on the Ethiopian people.

Another understanding of Federalism is best understood as a method of promoting 'self-rule' and 
'shared-rule,' which helps balance the nation's interests and regions or states. Typically, this is done for a dual purpose- that of preventive, the possibility of a tyranny of the majority and generating strength through union (Mitra and Phel, 2013). The core concept of Federalism came from the Constitution of the USA (1787), and then it was followed by others countries in the world like Australia, Canada, India, and Switzerland. After the second world war, Asian and African countries got independent, and that period is also known as a period of decolonization; most of the African and Asian countries like India, Nigeria were managing their diversity and unity for political stability through adopting the government based on federal structure, and later Ethiopia also followed the mechanism of Federalism for the protection of their diversity and ethnic identity. But many scholars start are with US (United States) federalism, as the core concept was institutionally developed by the US constitution. However, every federal system has its unique nature, based on a long historical experience, political, socio-cultural, and economic factors. According to Basu, the concept of Federalism is defined by scholars in a different context and for other countries. However, there may be some differences among scholars over the definitions of Federalism; there is consensus on some of the essential features of Federalism: dual government, the supremacy of the Constitution, distribution of powers, and authority of courts (Vasudeo, 2019), The definition of Federalism is not universal because the practice of Federalism justifies the uniqueness of Federalism. Also, the normative theory of Federalism emphasized norms, values, culture, and diversity. According to Burgess,

"Federalism requires a self-sustainable and robust institutional design (a federation), a complex, decentralized party system, and a set of attitudes and values: a shared political understanding that provides civic support for the system. In other words, Federalism cannot be reduced to the mechanics of the federation" (Burgess, 2006: 47).

\section{Ethnic Federalism in Ethiopian Political Structure}

Following the brutal, bloody civil war to topple the decade-old regime, the new TPLF regime captured and ratified a new constitution in August of 1995 . The Constitution made way for one-party dominance and not only gave TPLF the upper hand of power, but it left the Republic of Ethiopia with more than 80 ethnicities divided based on nine ethnic lines. But they were only giving way for four ethnicities to join the Federal Government.

But the consequences of this unconventional ethnicbased system did not stop its trouble there. For the last 30 years and sequences of events, Ethiopia, which was once regarded as a beauty of nation that spoke more than 80 languages with rich and varied culture and languages and ethnicities, became the reason for its chaos. And for three decades of the division was preached then what unified them together as a nation. The new generation was forced into believing he or she belonged to one ethnicity and one ethnic group.

The political parties were based on ethnic lines that claimed and held adequate land. Patriotism was replaced with nationalism. Fake and toxic rumours were spread, taught, and propagandized through educational history, which left one languagespeaking Ethiopians against the other. From the village of Arbagugu, 30 years ago to Maya Khadra today and the sequences of events, thousands of innocent lives were brutally murdered, hundreds of Churches were burnt, Priests and Orthodox Parishioners were burned alive and were forced into displacement from splitting the church to undermining its citizens. The regime that made orthodoxy and Ethnic Amharas its enemy, thereby unleashing its terror on Ethiopians, while the whole world watched in silence. On November 28th, 2020, after 30 years of terror, this group was brought to justice. The war on terror seems to be over and victorious, and Ethiopians are moving forward to a more inclusive and keeping intact its rich cultural and ethnic diversity.

But will Peace prevail in Ethiopia? The answer to this question is critical and vital from the point of view of keeping this cultural diversity intact.

Ethiopian Federalism has a unique feature as it defines itself as "Ethnic federalism" because it is based on ethnicity. The creation of ethnic Federalism provides recognition to ethnic identity in their political institutions, reflecting the innovative nature, and it can be differentiated from other 
federal systems. Semarang Gashu Abebe (2014), in his work on the political development in Africa, embraces the issue of "how can a nation make the transition from autocracy to democracy?" which the puzzling situation of emerging African states and other developing countries prevented them from making a proper political transition.

According to Abebe's view, most of the African states have adopted a centralized constitutional form of government following the examples of their formal colonial powers, mainly of France and of United Kingdom (Abebe, 2014, p. 1). In this case, Ethiopia stands as unique. As BertusPraeg explained that,

Most governments in Africa, seeing the political mobilization of ethnicity as a threat, have rejected the use of ethnic differences as an explicit basis for political representation. (BertusPraeg, 2006, p. 52).

Let us begin by noting that when interacting with lawmakers, scholars, or students from other African countries, they often say, "We don't understand Ethiopian politics" What are they going to do to institutionalize tribalism? This was Africa's only non-colonial republic, an indigenous state with some solidarity and a centralist tradition, and now they have followed us back to fragmentation (Abbink, 2011, p. 6).

In this situation, Ethiopia's notable exception began in 1991, when the Ethiopian People's Revolutionary Democratic Front (EPRDF) came to power, and the 1994 constitution is introduced, which initiated the principle of self-determination for nationalities (around 80) up to and including secession, devolving political, administrative, and economic power to ethnically established regional states.

In Ethiopia, the issue of ethnicity becomes much more critical, as it transfers the acknowledgment of ethnic identity and plurality to provide expression through the arch Ethiopian self-government based on ethnicity (ethnic origin) geography, as reflected in the federal arrangement. The EPRDF (Ethiopian Peoples' Revolutionary Democratic Party) introduced a federal system based on ethnic lines after militarily winning political control and overthrowing Ethiopia's Marxist military government in May 1991 (Teshome \& Záhořík, 2008).

Table 2: Administrative Regions and Their Ethnic composition

\begin{tabular}{ll}
\hline Region or City & Ethnic groups (in \%) \\
\hline Ethiopia & More than 80 ethnic groups \\
\hline Addis Ababa & $\begin{array}{l}\text { Amhara (56.04), Oromo (19.00), Gurage (16.34), Tigray (5.18), } \\
\text { Silt'e (2.94), and Gamo (1.68) and others }\end{array}$ \\
\hline Affair & Afar (90), Amhara (5.22), Argoba (1.55), Tigrie (1.15) and others \\
\hline Amhara & $\begin{array}{l}\text { Amhara (86.64), Agew-Awi (3.46), Oromo (2.62), AgewHamyra } \\
(1.39) \text { others }\end{array}$ \\
\hline Benishangul-Gumuz & $\begin{array}{l}\text { Berta (25.4), Amhara (21.6), Gumuz (20.9), Oromo (13.5), } \\
\text { Shinasha (7.7) others }\end{array}$ \\
\hline Dire Dawa & $\begin{array}{l}\text { Oromo (45.9), Somali (24.3), Amhara (20.1), Guragie (4.5) and } \\
\text { others }\end{array}$ \\
\hline Gambela & $\begin{array}{l}\text { Nawer (46.66), Ayiwak (21.16), Amhara (8.4), Kefficho (5.04), } \\
\text { Oromo (4.8) and others }\end{array}$ \\
\hline Harari & $\begin{array}{l}\text { Oromo (56.4), Amhara (22.77), Hariri (8.64), Guragie (4.33) and } \\
\text { others }\end{array}$ \\
\hline Oromia & $\begin{array}{l}\text { Oromo (87.8), Amhara (7.2), Guragie (0.91), Gedeo (0.8) and } \\
\text { others }\end{array}$ \\
\hline Somali & Somali (97.1), Amhara (0.66) and others \\
\hline Southern Nations, Nationalities, and \\
Peoples' Region & $\begin{array}{l}\text { Sidama (19.38), Welaita (10.5), Guragie (7.54), Gamo (6.99) and } \\
\text { others }\end{array}$ \\
\hline
\end{tabular}

$151 \mid$ This work is licensed under a Creative Commons Attribution 4.0 International License. 


\begin{tabular}{ll}
\hline Region or City & Ethnic groups (in \%) \\
\hline Tigray & $\begin{array}{l}\text { Tigre }(96.54), \text { Amhara (1.63), Irob (0.70), Affair (0.28), and } \\
\text { others }\end{array}$ \\
\hline Region 17 & $\begin{array}{l}\text { Somalia (71\%), Oromo (19.84\%), and few Burji, Amhara, Silte, } \\
\text { and many other ethnic groups }\end{array}$ \\
\hline Note: Most of the ethnic groups are not cited because the population is very small in percentage terms.
\end{tabular}

Source: Ethiopian Population Census 2007.

According to the 1994 Constitution, established the FDRE, Ethiopia is divided into nine states, Afar, Amhara, Benshangul-Gumaz, Tigrai, Gambela Peoples, Harari Peoples, Oromia, Somali, and Southern Nations Nationalities and Peoples (SNNP). Besides, Ethiopia has two chartered cities, Dire Dawa and Addis Ababa (Pandey D.N, 2006: 3 ). The nine regions are ethnically divided, and it is further subdivided into sixty-eight zones and then further into 550 woredas (districts) and several special woredas.

The capital city, Addis Ababa, is defined as a federal district. According to Cohen earlier, ethnicity was the criteria used in drawing boundaries. Now the Ethiopians have to get registered according to their ethnic group. Identification of ethnicity is not the undermining factor by Ethiopian law but the major factor for defining the groups based on their language. Although under the new Constitution, the country's official language is 'Amharic,' but all the Ethiopian languages enjoy equal recognition, and each state has the right to determine its respective official language. Each state has decided its administration, geographical size, agriculture, natural resources, infrastructure, and tax revenue. The Constitution has established the law of the land as supreme, taking precedence even over the customary law. It combines both the president and parliamentary form of government can minimize the separation of power and keep checks and balances (Cohen, 1995).

Briefly, under the Constitution :(1) right to the justice, freedom of speech, cultural heritage, voting right, and property are guaranteed, (2) supreme and independent judiciary, (3) right to choice of employment, (4) the federal government is headed by two government one is the Prime Minister, who is the real head of the state and another is the president, who nominal head of state, (5) the legislative function is performed by two parliamentary chambers, namely an upper house, or
Council of Federation (CF), appointed by ethnic groups or the councils of the States and a lower house, the Council of People's Representatives (CPR), comprised of representatives elected by secret ballot every five years; (6) the Prime Minister is selected by the dominant party in the lower house of elected representatives, (7) States have, some specified conditions, the seceding; "Every nation, nationality and people shall have the unrestricted right to self- determination up to secession" (Article 39), (8) the Prime Minister and the council of ministers are accountable to the lower house, (9) states decide their own official language, establish their own government institutions and organizations, authorized tax powers, establish separate police forces, (10) the role of national government sets the national policies, guidelines, and regulations (John M. Cohen 1995, pp.; 165166). These are the major provisions of the Constitution that reflect the diversity and promote ethnic identity through the federal structure. Although, the opposition party of OLF (Oromo Liberation Front) had argued that the TGE (Transitional Government of Ethiopia) would never support giving the right to secede from States. Hence, it is not easy to secede under constitutional laws because some specific political procedures make it very hard to secede. The act of secession requires at least two-thirds vote of the seceding ethnic group in the legislature to be followed three years later by a referendum in the seceding region (Habtu, 2003). However, TGE (The Transitional Government of Ethiopia, TGE) allowed the right to enter the Constitution because it could help end the kind of arms conflict that can lead to the independence of Eritrea.

The Constitution gives states that either they come together to make larger or make a small group of states. It provides little guidance to the management of the federal-regional relations dealing with border disputes between inter-states. Article 48 stipulates settlement by bilateral agreement among the 
disputant states. If the parties could not reach an agreement, then the house of the federation will decide based on settlement patterns and wishes of the people concerned. Article 50 only stipulates the general need for mutual, reciprocal respect between federal and regional governments (Habtu, 2003). The Ethiopian Constitution gives in larger space to states for the development and political selfsufficiency of governance, reflecting the core significance of ethnicity in Ethiopian politics. It can sound vibrant democratization of ethnicity.

\section{CONCLUSION}

According to Malakar, "Agrarian Transformation and Political Dynamics in Ethiopia" explains the emergence of Ethiopia as the first country in Africa to give recognition to the ethnic groups as the sole factor of political formations. People are grouped and addressed based on their ethnic identities; the administration, "multi-party" politics is based on ethnicity; and even the Parliament is composed of ethnic parties. (After the overthrown of the military regime by the EPRDF, the new regime conducted a national conference in July 1991 in which all the ethnic groups were invited and asked to send their representatives to make a new political system for the Ethiopian people. Thus, the emergence of the Ethiopian federal states with the core concept of ethnic Federalism was determined by a keen interest in articulating the ethnic groups (Malakar 2006).

The Ethiopian ethnic groups witnessed the threetime major shift of political regime; first, the emperor regime, second the Derg military rule from 1974 till 1991; under both the powers, ethnic groups were undermined under the narrow-minded nationalism. The ethnic tension and conflicts were also expanding under military rule. The third and the foremost transition era of Ethiopian politics from 1991 till 1995 during this time, all the ethnic group's representatives were invited to form the Ethiopian Constitution. All the ethnic groups supported the establishment of the ethnic federal system based on their indigenous culture and ethnicity for equal rights and representation under the Ethiopian political system. Finally, EPRDF achieved establishing a new constitution by 1995 , which was determined by ethnic Federalism. Although some critical views have come from the scholars that ethnic Federalism could not sustain for a long time as ethnic conflicts will remain. Institutions based on ethnic loyalty can create a problem for national unity, and thus reform shall be necessary. But the other side of the optimistic view of the ethnicity of Ethiopian Federalism is that it was created for resolving the conflicts and not to create ethnic tensions. Hence there were some challenges in the initial transition phase, and it is still facing some ethnic conflicts, but the representation of ethnic groups can resolve the disputes and maintains diversity and unity among them. Ethnic Federalism is a crucial feature of Ethiopian politics. Also, it successfully retains their diversity and extends the democratization (democratizing) process, and ensures a sustained economic growth rate and educational coverage. In the long run, ethnic Federalism will flourish the diversity and identity shared between the three major ethnic groups (the Oromo, the Amhara, and the Tigray). Therefore, the ruling groups should be making policies and regulations in a pluralistic way to maintain equal development and control to interstate disputes.

In conclusion, the Ethiopian political structure defined by ethnic groups and its practice as an ethnic federation gives new phenomena in the world, giving more ethnic recognition and representation under the political system; it also reflects the maintenance of ethnic heritage as the core part of the Ethiopian politics. Although the dark part of this power politics between the centre and states, which is the recent time Tigray crises, fighting between the Ethiopian army and Tigray People's Liberation Front (TPLF), is created an unpredictable situation for the northern part of the Ethiopian politics. In contrast, the core idea of the Ethiopian Constitution is resolving the ethnic conflicts between ethnonalism and states. The reality is that most ethnic groups appear seeking to live within the framework of the federal structure is, in part, as a result, achievement of ethnic Federalism-the Ethiopian federal system in its constitutional which has included political pluralism and the right of secession. But currently, much-needed cooperation between the major three ethnic groups, the Oromo, the Amhara, and the Tigray. Also, Ethiopia needs to establish good and normal relations with all its neighbouring countries as co-ethnics communities are residing in all of them. 


\section{REFERENCES}

Aalen, L. (2002). Ethnic Federalism in a dominant party state: The Ethiopian experience 19912000. CMI Report, 2002(2).

Abebe, G. S. (2014). The Last Post-Cold War Socialist Federation - Ethnicity, Ideology, and Democracy in Ethiopia, England: Ashgate Publishing Ltd.

Abebe, T. (2016). Ethiopia: A call for Constitutional reform, http://nazret.com/blog/index.php/2016/01/22/et hiopia-a-call-for-constitutional.

Abbink, J. G. (1998). New configurations of Ethiopian ethnicity: the challenge of the South. Northeast African Studies, 5(1), 59-81.

Abbink, J. (2011). Ethnic-based Federalism and ethnicity in Ethiopia: reassessing the experiment after 20 years. Journal of Eastern African Studies, 5(4), 596-618.

Alam, H. (2003). Ethnic Federalism in Ethiopia: Background, present conditions and future prospects.

Alemayehu, A. N. (2004). Ethnic Federalism in Ethiopia: Challenges and opportunities.

Adeney, K. (2017). Does ethnofederalism explain the success of Indian Federalism. India Review, 16(1), 125-148.

Balcha, B. G. (2008). Ethnicity and restructuring of the state in Ethiopia. Aalborg: Department of History. International and Social Studies, Aalborg University.

Burgess, M. (2006). Comparative Federalism Theory and Practice. Abingdon, Ox.

Basu, D. D. (1976). Introduction to the Constitution of'India, New Delhi.

Cohen, J. M. (1995). " Ethnic Federalism" in Ethiopia. Northeast African Studies, 2(2), 157188.
Erk, J. (2017). 'Nations, Nationalities, and Peoples': The Ethnopolitics of Ethnofederalism in Ethiopia. Ethnopolitics, 16(3), 219-231.

Ethiopian Population Census 2007, URL: http://catalog.ihsn.org/index.php/catalog/3583.

Fiseha, A. (2012). Ethiopia's Experiment in Accommodating Diversity: 20 Years' Balance Sheet. Regional \& Federal Studies, 22(4), 435473.

Frank, M. (2009). Effects of ethnic Federalism in Ethiopia: Holding together or splitting apart. Ethnicity, Diversity and Democracy.

Glass, H. E. (1977). Ethnic diversity, elite accommodation and Federalism in Switzerland. Publius, 7(4), 31-48.

Halabo, T. T. (2016). Ethnic Federal System in Ethiopia: Origin, Ideology and Paradoxes. Inter. J. Polit. Sci. Develop, 4, 1-15.

Habtu, A. (2003). Ethnic Federation in Ethiopia: Background, Present Conditions and Future Prospects. International Conference on African Development.

Hagmann, T. (2006). Ethiopian political culture strikes back: a rejoinder to J. Abbink. African Affairs, 105(421), 605-612.

Keller, E. J. (2002). Ethnic Federalism, fiscal reform, development, and democracy in Ethiopia. African Journal of political science, 7(1), 21-50.

Kyel, S. (2011), "Federalism: A Normative Theory and Its Practical Relevance", the Continuum International Publishing Group, S1147250.

Keller, E. J. (2002). Ethnic Federalism, fiscal reform, development and democracy in Ethiopia. African Journal of political science, 7(1), 21-50.

Mengisteab, K. (1997). New approaches to state building in Africa: the case of Ethiopia's ethnicbased Federalism. African Studies Review, 40(3), 111-132. 
Mengie, L. T. (2016). Federalism as an Instrument for Unity and the Protection of Minorities: A Comparative Overview: Ethiopia, India and the US. Mizan Law Review, 10(2), 265-295.

Mesfin, S. (2017). Ethiopian Ethnic Federalism: Without a Space for 'Indigenous Peoples'? Ethnopolitics, 16(3), 246-259.

Malakar, S. N. (2006). Agrarian Transformation and Political Dynamics in Ethiopia. Academic Excellence.

Matsuzato, K. (2017). The Rise and Fall of Ethnoterritorial Federalism: A Comparison of the Soviet Union (Russia), China, and India. Europe-Asia Studies, 69(7), 1047-1069.

Praeg, B. (2006). Ethiopia and political renaissance in Africa. Nova Publishers.

Stanovčić, V. (1992). Problems and options in institutionalizing ethnic relations. International Political Science Review, 13(4), 359-379.

UNESCO. (2017). Diversity of Cultural Expressions, Ethiopia Report, 2017, URL: https://en.unesco.org/creativity/monitoreo-einformes/informes-periodicos/informes-109.

Vasudeo, K. (2019)., Dimensions of Federalism in Developing Countries: A Comparative Analysis of India and Ethiopia (1991-2017). Mahatma Gandhi Central University Journal of Social Sciences MGCUJSS, I (1).

Teshome, W., \& Záhořík, J. (2008). Federalism in Africa: The case of ethnic-based federalism in Ethiopia. Journal of Human Sciences, 5(2). 